UDC 339.16.012.332

DOI: https://doi.org/10.32840/1814-1161/2021-1-6

\author{
Yasynska Nadiia \\ Doctor of Economics Sciences, \\ Professor of Finance, Accounting and Taxation Department \\ Donetsk State University of Management
}

Romaniuta Valeriia

Student of the Faculty of Economics Donetsk State University of Management

Ясинська Н.А. доктор економічних наук, профресор кафедри фрінансів, обліку і оподаткування Донецького державного університету управління

Романюта B.C.

студентка економічного фракультету Донецького державного університету управління

\title{
FEATURES OF ELECTRONIC PUBLIC PROCUREMENT DURING COVID-19
}

\section{ОСОБЛИВОСТІ ПРОВЕДЕННЯ ЕЛЕКТРОННИХ ДЕРЖАВНИХ ЗАКУПІВЕЛЬ ПІД ЧАС COVID-19}

In Ukraine on 12 March 2020 was first introduced quarantine to prevent the spread of the country coronavirus COVID-19. At the same time, a new type of procurement appeared- "Procurement to prevent the COVID-19 pandemic". All of humanity is at risk of coronavirus infection. The purchase of protection products, medicines, disinfectants is necessary for everyone, but unfortunately this topic is insufficiently studied in our country, although it is quite relevant today. The article considers the procedure of such procurement, identifies the structures that control customers for the correctness of simplified procurement procedures. Also, the study analyzed the number of purchases, the amounts for which contracts were concluded, the amount of funds spent in each region of Ukraine and the distribution of these funds into different categories of goods. During the study, the problems were identified that arise during this type of procurement. Customer's errors were analyzed and methods for solving them were considered.

Keywords: government procurement, procurement COVID-19 customers, e-procurement system, coronavirus, procurement.

На території України з 12 березня 2020 року вперше було введено карантин задля запобігання поширенню на території країни коронавірусу COVID-19. Разом з цим з'явився новий вид закупівель - «Закупівля для запобігання пандемії COVID-19». У зоні ризику зараження коронавірусом знаходиться усе людство. Закупівля товарів захисту, медикаментів, дезінфрікуючих засобів необхідна усім, але на жаль дана тема $є$ недостатньо вивченою у нашій країні, хоча є досить актуальною у наш час. У статті розглянуто процедуру проведення таких закупівель, визначено структури, які контролюють замовників на правильність проведення спрощених процедур закупівлі. Також проаналізовано кількість закупівель та суми на які було укладено договори, кількість витрачених коштів кожною областю України та розподіл цих коштів на різні категорії товарів. Оскільки при проведенні даного виду закупівель виникають певні проблеми та помилки у замовників, то під час проведення дослідження їх було визначено та розглянуто методи їх вирішення.

Ключові слова: державні закупівлі, закупівлі COVID-19, замовники, електронна система закупівель, коронавірус, закупівлі.

На территории Украины с 12 марта 2020 впервые был введен карантин для предотвращения распространения на территории страны коронавируса COVID-19. Вместе с этим появился новый вид закупок«Закупка для предотвращения пандемии COVID-19». В зоне риска заражения коронавирусом находится все человечество. Закупка товаров защиты, медикаментов, дезинфицирующих средств необходимо всем, но к сожалению данная тема недостаточно изучена в нашей стране, хотя является весьма актуальной в наше время. В статье рассмотрены процедуры проведения таких закупок, определены структуры, которые контролируют заказчиков на правильность проведения упрощенных процедур закупки. Также проанализированы количество закупок и суммы на которые были заключены договора, количество потраченных средств каждой областью Украины и распределение этих средств на различные категории товаров. 
Поскольку при проведении данного вида закупок возникают определенные проблемы и ошибки у заказчиков, то во время проведения исследования они были определены и рассмотрены методы их решения.

Ключевые слова: государственные закупки, закупки COVID-19, заказчики, электронная система закупок, коронавирус, закупки.

Problem statement. In modern conditions, since the introduction of quarantine in Ukraine, the question of the peculiarities of electronic public procurement in the fight against COVID-19, as they are the basis for providing various enterprises and institutions with personal protective equipment, disinfectants, medicines and everything necessary to combat acute respiratory disease. One of the main conditions for successful procurement is: knowledge of regulations on the basis of which procurement is carried out, following the procurement procedure and avoiding possible mistakes in their conduct.

Purpose of the study is to consider the features of e-procurement in the fight against COVID-19 and to analyze the problems and errors that arise in customers when conducting this type of procurement.

Overview of recent research and studies. The issue of conducting electronic public procurement in the fight against COVID-19 is new, very relevant and insufficiently studied in our country. Currently, only journalists' articles and information on various Prozzoro sites are publicly available for information on this type of procurement. It is necessary to scientifically describe, develop and systematize objective knowledge about the reality of the practice of control of public and medical institutions against coronavirus, further study of the peculiarities of procurement to combat COVID-19.

Research results. In Ukraine the standards Cabinet of Ministers of Ukraine №211 was first introduced quarantine from 12 March 2020 to 22 May 2020 throughout the Ukraine to prevent the spread of the country coronavirus COVID-19 [1].

Atthesametime, anewtypeofprocurementappeared"Procurement to prevent the COVID-19 pandemic" public customers were allowed to purchase essential goods and services without auctions, sign and publish reports without using an electronic procurement system. The legal basis for this process was the Resolution of the Cabinet of Ministers of Ukraine №225 of 20 March 2020 [2]. This document contains a list of goods, works and services necessary to implement measures aimed at preventing the occurrence and spread, localization and elimination of outbreaks, epidemics and pandemics of acute respiratory disease COVID-19 caused by the coronavirus SARS-CoV-2 in Ukraine.

To purchase goods (medical equipment, personal protective equipment, consumables, medical devices, etc.) in the contract it is necessary to refer to the Resolution of the Cabinet of Ministers of Ukraine №225 and indicate the code according to the Ukrainian Classification goods of Foreign Economic Activity for identification by regulatory authorities the relation of the given goods to the resolution. In the case of procurement of drugs and immunobiological drugs, the contract also states the international non-proprietary name of the drug and dosage, and when purchasing antiseptics and disinfectants - the name of the main component and the content of the active substance.
Medical institutions, which were included in the list of first-wave hospitals by the order of the Chief State Sanitary Doctor of Ukraine № 7 of 27 March 2020 [3], accepted patients with coronavirus and were among the first to be involved in procurement without tenders. At that time, one of the conditions for such a procurement was a restriction - the publication of information about the procurement in the electronic procurement system (conclusion of the contract) not earlier than 48 hours after the publication of the plan. It should be noted that today this type of procurement has an updated procedure, which consists of the following stages:

1. The customer must appoint an authorized person who will be determined by him responsible for the organization and conduct of this type of procurement.

2. All procurements are conducted in compliance with the principles set out in the Law of Ukraine "On Public Procurement" [4], the main of which are - reducing corruption, saving budget funds and the presence of fair competition among participants in public procurement.

3. During procurement, customers are guided by the Constitution and laws of Ukraine, decrees of the President of Ukraine and resolutions of the Verkhovna Rada of Ukraine adopted in accordance with the Constitution and laws of Ukraine, acts of the Cabinet of Ministers of Ukraine and other legislation.

4. The customer must display the product, work or service that he intends to purchase in the annual procurement plan in the electronic system. It is also necessary to organize and conduct the procurement, provided that he can independently establish the criteria of integrity and reliability of the choice of the person with whom the procurement contract will be concluded.

After that, the customer ensures the preparation, approval and storage of relevant documents on procurement and subsequent publication in the electronic procurement system.

The control over the correctness of the procedure of procurement of goods, works or services is carried out at the local level by the tender department of the city and if the procurement was financed from the budget, the contract and the procurement itself are also checked by the State Treasury Service of Ukraine. In general, all procurements should be monitored by the State Audit Office and the Antimonopoly Committee of Ukraine.

The State Audit Office is to be the vanguard of the struggle for effective procurement, but it pays little attention procurement of COVID-19. The auditors explain that they lack authority [10]. In particular, they cannot promptly respond to violations and come to customers with audits if necessary. They have the right to check one customer only once a year. The situation can be remedied by amending regulations, but auditors must prioritize such procurement themselves. Otherwise, even the expansion of the powers of the main control body will not bring changes.

Significant contribution to the inspection and supervision of procurement to combat coronavirus is 
made by public organizations, which in case of violation address an official letter to the customer with a request for clarification, auditors to organize the inspection or the Antimonopoly Committee of Ukraine.

It would seem that such an approach to the organization of procurement should facilitate the work of customers and speed up the procurement procedure. And market pricing mechanisms should be smoothed out by government infrastructure, regulations and procedures. However, the first problems arise during the monitoring of the price of essential goods. For example, from the beginning of the introduction of the possibility of procurement without an auction, customers began to actively buy goods to protect personnel (masks, protective overalls, hats, shields, gloves, etc.). Demand was much higher than supply of these types of goods, there was a deficit. Under these conditions, suppliers raised prices several times, as they understood that in the event of an urgent need for a particular type of product, customers will agree to any price. For example, consider how the price of protective medical masks changed from January to June 2020 (Table 1).

That is, the lowest average price was at the beginning of the year - in January it was $0,98 \mathrm{UAH}$, and in February 1,02 UAH - which can be explained by the fact that at that time all purchases were made according to competitive procedures. In March the price has increased dramatically due to the shortage of this type of product, but gradually from the end of April, the price began to decline it is possible to conclude that the market began to saturate medical masks [6].

It also takes a lot of time to check the supplier for compliance with the criteria of integrity and reliability of the person with whom the procurement contract will be concluded (certificate of absence of tax arrears; a certificate stating that the person is not prosecuted, has no unresolved or outstanding criminal record and is not wanted; certificate that the person has not been declared bankrupt in accordance with the procedure established by law and liquidation proceedings have been opened against him, etc.).

It should also be noted that the State Budget of Ukraine in 2020 established a fund to combat acute respiratory disease COVID-19, and its consequences for the quarantine period established by the Cabinet of Ministers of Ukraine to prevent the spread of the disease in Ukraine, and for 30 days from the date of cancellation of this quarantine. The funds of this fund should be directed primarily to:

1) for the purchase of goods, works and services necessary for the implementation of measures aimed at preventing the occurrence and spread, localization and elimination of outbreaks, epidemics and pandemics of acute respiratory disease COVID-19, including the purchase of medical services under the program of state guarantees of medical care, purchase equipment for health care support facilities and overhaul, reconstruction of these premises, improvement of transport links, construction, reconstruction, repair and maintenance of public roads of state and local importance;

2) additional surcharges to the salaries of medical and other employees who are directly employed in the liquidation of COVID-19;

3) providing one-time cash benefits to family members of medical and other health care workers who have died from COVID-19 [7].

According to the Dozorro monitoring website, from 18 March 2020 to 1 December 2020, 103836,00 purchases were made with the label "Report on the concluded contract (COVID-19)" in the amount of 16.3 billion UAH.

The largest amounts for the fight against coronavirus were spent in Kyiv (7,06 billion UAH), Odessa (799,24 million UAH), Dnipropetrovsk (779,42 million $\mathrm{UAH})$ and Lviv (733,73 million UAH) areas.

Also in this period were made different types of procurement (goods and services) (Figure 1).

The largest amounts were spent on the purchase of medical equipment $(8,76$ billion $\cup A H)$, pharmaceuticals (3,96 billion UAH), motor vehicles $(0,71$ billion $U A H)$, emergency and security equipment ( 0,50 billion $U A H)$, etc. [5].

It should be noted that during procurement in the fight against COVID-19 spending units suggest some errors that prolongs the procurement procedure until they are corrected. First, customers enter into contracts without processing the market and confirming the current market price. They are required to enter into an agreement after mandatory market processing and registration of a competitive letter with at least three relevant proposals and the reasons for determining the winner.

Secondly, sometimes customers in the contract do not prescribe references to regulatory documents in accordance with which the purchase is made (Resolution of the Cabinet of Ministers of Ukraine №225), or do not specify references to UKTZED product codes that can be identified - whether the customer can buy this product on the terms of procurement in the fight against COVID-19. That is why some customers, due to ignorance or intentionally, buy goods that are not subject to a certain list under the simplified COVID-19 procedure.

Table 1

Prices and volumes of purchases of medical masks in the period from 01.01 .2020 to 30.06 .2020 [6]

\begin{tabular}{|l|c|c|c|c|c|c|}
\hline & January & February & March & April & May & June \\
\hline Number of purchases, pcs. & 30 & 76 & 284 & 777 & 675 & 1517 \\
\hline $\begin{array}{l}\text { Number of masks } \\
\text { purchased, pcs. }\end{array}$ & 108550 & 547592 & 2072819 & 10327078 & 7677545 & 8897201 \\
\hline $\begin{array}{l}\text { The cost of purchased } \\
\text { masks, UAH }\end{array}$ & 106547,33 & 557263,79 & 26777049,26 & 134573727,68 & 61682314,14 & 48053234,99 \\
\hline Average price, UAH & 0,98 & 1,02 & 12,92 & 13,03 & 8,03 & 5,40 \\
\hline Median price, UAH. & $0,50-1,10$ & $0,70-3,20$ & $1,60-15,00$ & $9,70-16,80$ & $3,00-11,80$ & $6,10-11,10$ \\
\hline
\end{tabular}




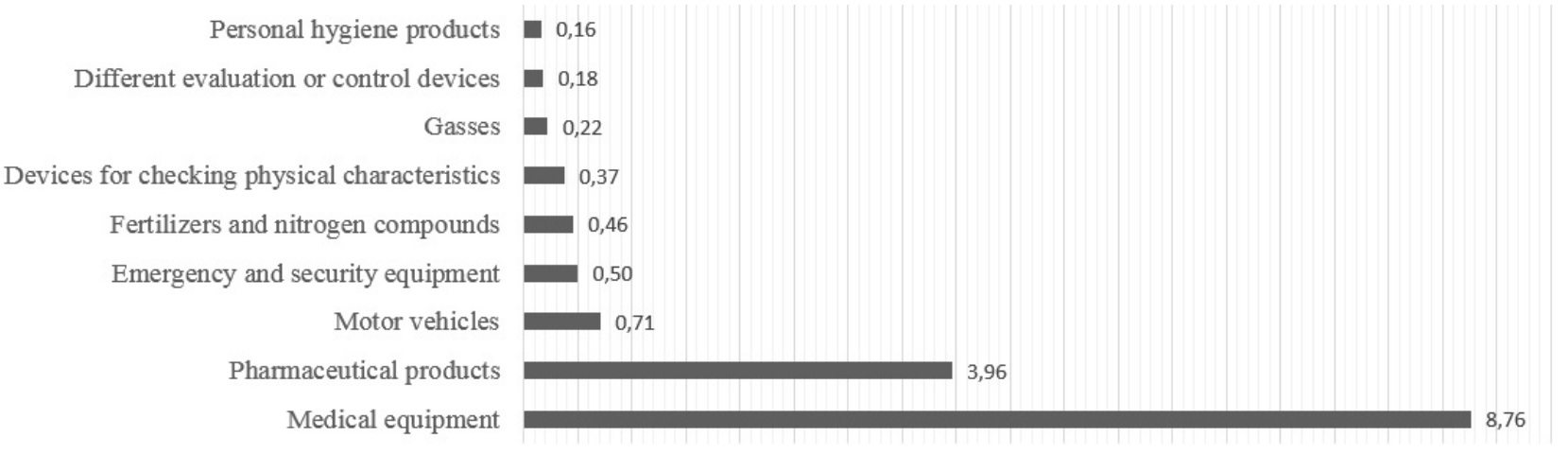

$\begin{array}{llllllllllllllllllllll}0,00 & 0,50 & 1,00 & 1,50 & 2,00 & 2,50 & 3,00 & 3,50 & 4,00 & 4,50 & 5,00 & 5,50 & 6,00 & 6,50 & 7,00 & 7,50 & 8,00 & 8,50 & 9,00 & 9,50\end{array}$

Figure 1. Type of goods in Prozorro COVID-19 purchases, billion UAH [5]

Third, one of the main conditions for procurement necessary to implement measures to prevent coronavirus is the publication of a contract under the reporting procedure with the indication in the electronic system "Procurement to prevent the pandemic COVID-19", without which procurement in the electronic system will have to cancel and create a new one, which also takes a lot of time.

Fourth, the procurement will be considered invalid if the customer in the electronic procurement system does not provide information about the ultimate beneficial owner of the legal entity with which the customer has entered into a procurement contract. This information must be taken from the official portal of the Ministry of Justice of Ukraine [8] and must be provided when conducting procurement aimed at preventing COVID-19.

Fifth, customers should be aware that the Resolution of the Cabinet of Ministers of Ukraine № 224 of 20 March 2020 [9] approved the list of goods (including medicines, medical devices and medical equipment) necessary for the implementation of measures aimed at preventing occurrence and spread, localization and elimination of outbreaks, epidemics and pandemics of acute respiratory disease COVID-19 caused by coronavirus SARS-CoV-2, the import of which into the customs territory of Ukraine and the supply of which in the customs territory of Ukraine are exempt from taxation cost. That is, if the customer buys a certain product to prevent coronavirus with value added tax, indicating the Resolutions of the Cabinet of Ministers of Ukraine № 224 and № 225, it will be illegal.

In this case, it is necessary to sign an additional agreement to reduce the amount of the contract by the amount of value added tax, or - if the supplier can't sell goods without value added tax - terminate the contract with this supplier and look for a new contract in accordance with procurement procedures aimed at preventing acute respiratory disease COVID-19.

Conclusions. Therefore, the study identified an updated procurement procedure to prevent and combat COVID-19, problems and errors that arise in customers during their conduct and methods of solving them.

In conclusion, the procurement of goods, works and services under the simplified procurement procedure in the fight against COVID-19 fully justified itself at the beginning of the epidemic, but now is the time to return to efficient and controlled procurement. The situation of uncertainty and panic is over. According to the Ministry of Health, most support hospitals are provided with personal protective equipment for several months even in the worst case scenario, and some procurement has been centralized. Also, it should be noted that in conditions of healthy competition in the market, customers will use the funds much more efficiently.

\section{References:}

1. Pro zapobighannja poshyrennju na terytoriji Ukrajiny ghostroji respiratornoji khvoroby COVID-19 (2020) [About prevention of distribution on the territory of Ukraine of an acute respiratory illness COVID-19]: Postanova KMU № 211 vid 11.03.2020. Available at: https://zakon.rada.gov.ua/laws/ show/211-2020-п\#Text (accessed 20 December 2020).

2. Dejaki pytannja zakupivli tovariv, robit i poslugh, neobkhidnykh dlja zdijsnennja zakhodiv, sprjamovanykh na zapobighannja vynyknennju ta poshyrennju, lokalizaciju ta likvidaciju spalakhiv, epidemij ta pandemij ghostroji respiratornoji khvoroby COVID-19, sprychynenoji koronavirusom SARS-CoV-2, na terytoriji Ukrajiny (2020) [Some issues of procurement of goods, works and services necessary for the implementation of measures aimed at preventing the occurrence and spread, localization and elimination of outbreaks, epidemics and pandemics of acute respiratory disease COVID-19 caused by coronavirus SARS-CoV-2, in Ukraine]: Postanova KMU № 225 vid 20.03.2020. Availableat:https://zakon.rada.gov.ua/laws/show/225-2020n\#Text (accessed 20 December 2020).

3. Official site of the Ministry of Health of Ukraine. Available at: https://moz.gov.ua/golovnij-derzhavnij-sanitarnij-likarukraini (accessed 20 December 2020).

4. Pro publichni zakupivli (2015) [About public procurement] Zakon Ukrajiny № 922-VIII vid 25.12.2015. Available at: https://zakon.rada.gov.ua/laws/show/922-19\#Text (accessed 20 December 2020).

5. Procurement Prozorro COVID-19. Available at: https://covid.dozorro.org/ (accessed 20 December 2020).

6. Pylypenko Ja. (2020) Zakupivli masok u Prozorro: jak zminjuvalysja ciny [Purchase of masks in Prozorro: how prices have changed]. Available at: https://dozorro.org/blog/ yak-zminyuvalisya-cini-na-medichni-maski-v-prozorroprotyagom-piv-roku (accessed 20 December 2020).

7. Pro Derzhavnyj bjudzhet Ukrajiny na 2020 rik (2019) [About the State Budget of Ukraine for 2020]. Zakon Ukrajiny № 294-IX vid 14.11.2019. Available at: https://zakon.rada.gov.ua/laws/ main/294-IX\#Text (accessed 20 December 2020).

8. Official site of the Ministry of Justice of Ukraine. Available at: https://usr.minjust.gov.ua/content/free-search (accessed 20 December 2020).

9. Pro zatverdzhennja pereliku tovariv (u tomu chysli likarsjkykh zasobiv, medychnykh vyrobiv ta/abo medychnogho obladnannja), neobkhidnykh dlja vykonannja zakhodiv, 
sprjamovanykh na zapobighannja vynyknennju i poshyrennju, lokalizaciju ta likvidaciju spalakhiv, epidemij ta pandemij ghostroji respiratornoji khvoroby COVID-19, sprychynenoji koronavirusom SARS-CoV-2, operaciji z vvezennja jakykh na mytnu terytoriju Ukrajiny ta/abo operaciji z postachannja jakykh na mytnij terytoriji Ukrajiny zviljnjajutjsja vid opodatkuvannja podatkom na dodanu vartistj (2020) [About prevention of distribution on the territory of Ukraine of an acute respiratory illness COVID-19]. Postanova KMU № 224 vid 20.03.2020. Available at: https://zakon.rada.gov.ua/laws/ show/224-2020-n\#Text (accessed 20 December 2020).

10. Lakhtionov I. (2020) Zakupivli dlja borotjby z COVID-19: pidkhody potribno zminjuvaty [Procurement to combat COVID-19: approaches need to change]. Available at: https://ti-ukraine.org/blogs/zakupivli-dlya-borotby-z-covid-19pidhody-potribno-zminyuvaty/ (accessed 20 December 2020).

\section{Бібліографічний список:}

1. Про запобігання поширенню на території України гострої респіраторної хвороби COVID-19, спричиненої коронавірусом SARS-CoV-2 : постанова Каб. Міністрів України від 11.03.2020 р. № 211. Законодавство України : база даних / Верхов. Рада України. Дата оновлення: 12.12.2020. URL: https://zakon.rada.gov. ua/laws/ show/211-2020-п\#Text (дата звернення: 20.12.2020).

2. Деякі питання закупівлі товарів, робіт і послуг, необхідних для здійснення заходів, спрямованих на запобігання виникненню та поширенню, локалізацію та ліквідацію спалахів, епідемій та пандемій гострої респіраторної хвороби COVID-19, спричиненої коронавірусом SARSCoV-2, на території України : постанова Каб. Міністрів України від 20.03.2020 р. № 225. Законодавство України : база даних / Верхов. Рада України. Дата оновлення: 10.12.2020. URL: URL: https://zakon.rada.gov.ua/laws/ show/225-2020-п\#Text (дата звернення: 20.12.2020).

3. Офіційний сайт Міністерства охорони здоров'я України. URL: https://moz.gov.ua/golovnij-derzhavnij-sanitarnijlikar-ukraini (дата звернення: 20.12.2020).
4. Про публічні закупівлі : Закон України від 25.12.2015 p. №922-VIII. Законодавство України : база даних / Верхов. Рада України. Дата оновлення: 20.12.2020. URL: https://zakon.rada.gov.ua/laws/show/922-19\#Text (дата звернення: 20.12.2020).

5. Закупівлі Prozorro COVID-19. URL: https://covid.dozorro. org/ (дата звернення: 20.12.2020).

6. Пилипенко Я. Закупівлі масок у Prozorro: як змінювалися ціни. URL: https://dozorro.org/blog/yak-zminyuvalisyacini-na-medichni-maski-v-prozorro-protyagom-piv-roku (дата звернення: 20.12.2020).

7. Про Державний бюджет України на 2020 рік : Закон України від 14.11.2019 р. № 294-ІХ. Законодавство України : база даних / Верхов. Рада України. Дата оновлення: 10.12.2020. URL: https://zakon.rada.gov.ua/laws/ main/294-IX\#Text (дата звернення: 20.12.2020).

8. Офіційний сайт Міністерства юстиції України. URL: https://usr.minjust.gov.ua/content/free-search (дата звернення: 20.12.2020).

9. Про затвердження переліку товарів (у тому числі лікарських засобів, медичних виробів та/або медичного обладнання), необхідних для виконання заходів, спрямованих на запобігання виникненню і поширенню, локалізацію та ліквідацію спалахів, епідемій та пандемій гострої респіраторної хвороби COVID-19, спричиненої коронавірусом SARS-CoV-2, операції 3 ввезення яких на митну територію України та/або операції з постачання яких на митній території України звільняються від оподаткування податком на додану вартість : постанова Каб. Міністрів України від 20.03.2020 р. № 224. Законодавство України : база даних / Верхов. Рада України. Дата оновлення: 17.12.2020. URL: https://zakon.rada.gov.ua/laws/show/224-2020п\#Техt (дата звернення: 20.12.2020).

10. Лахтіонов І. Закупівлі для боротьби з COVID-19: підходи потрібно змінювати. URL: https://ti-ukraine.org/ blogs/zakupivli-dlya-borotby-z-covid-19-pidhody-potribnozminyuvaty/ (дата звернення: 20.12.2020). 